\title{
OPERATION ANALYSIS OF PHOTOVOLTAIC PANELS LOADED UNDER CONSTANT ELECTRIC LOAD
}

\author{
Imants Ziemelis, Liene Kancevica, Ilze Pelece, Henriks Putans, Adolfs Rucins \\ Latvia University of Life Sciences and Technologies, Latvia \\ liene.kancevica@1lu.lv, ilze.pelece@1lu.lv, henriksooo@inbox.lv, adolfs.rucins@1lu.lv
}

\begin{abstract}
Usually additional devices are used to connect the consumers to solar panels, which can be quite complex and expensive, such as solar inverters, electric batteries, battery charge/discharge controllers and others. Therefore, the aim of this work is to look for possibilities for direct connection of solar panels to the electricity consumers with active load resistance (electric heaters) and, at the same time, to ensure maximum capacity of the electricity produced by the solar panels by adjusting for this purpose the voltage (number of panels) of the solar panels to the value of the load resistance of the consumer, so that during the season the solar panels will operate longer (more) in the peak power point area of the solar panels. An experiment was conducted between February 1 and October 31, 2018 and 2019, during which the daily amounts of the energy generated by four solar panels SoletP6.60-WF-250 (273 days in total) were loaded with 3.5; 4.5; 6.5 and $8.4 \Omega$ electrical resistance. Processing the recorded data showed that most energy $-212.4 \mathrm{kWh}$ - was generated by a $4.5 \Omega$ loaded solar panel, which on a clear day (04/29/2019) had the power and energy transfer rates of $15.6 \%$ and $14.22 \%$, respectively. Least energy $-180.3 \mathrm{kWh}$ was produced by an $8.4 \Omega$ loaded solar panel. All the four panels together produced $788.6 \mathrm{kWh}$. It has been found that, at a loss of $2 \%$ of the produced power, the load resistance of the solar panel SoletP6.60-WF-250 could be within the range of 4 to $5.5 \Omega$. By using the statistical frequency function in the data processing the power and energy production characteristics of differently loaded solar panels are explained. By a calculation example there is shown the principle of direct connection of the standard 2 and 4 $\mathrm{kW}$ electric heaters to the solar panels.
\end{abstract}

Keywords: PV panels, power, energy load.

\section{Introduction}

Latvia, by its geographical situation, is located at 57 degrees latitude, which is characterised by a long $(\sim 18 \mathrm{~h})$ and rich in solar radiation day in the middle of summer, when the sun makes an around 270 degrees circle in the sky and rises 57 degrees above the horizon at noon. Taken together, a significant amount of solar energy per day can be obtained in a period between March and September, including. Quite a small amount of the obtained solar energy in Latvia is usually produced per day between November and March.

Among the most widely applied wiring schemes for solar panels the most widespread are two schemes - the autonomously operating one and the connected to the electric network [1-4]. In essence, the autonomous devices can be divided into the low voltage and the electric network voltage devices. In the low-voltage installations the solar panels with the charge-discharge current controllers are connected to the electric accumulators, where the stored energy is used to operate various low-voltage devices, for example, the lighting devices, hand-held power tools - drills, screwdrivers [5].

By connecting the appropriate voltage converter (inverter) to the battery, it is also possible to supply (operate) the devices intended for the network voltage. The inverters, intended for solar panels, are divided into two groups - the inverter connected to the electric network (the ON Grid inverters) and the autonomous inverters (the OFF Grid inverters). They may be equipped with or without the search function of a maximum power point (MPPM). The inverters equipped with an MPPM are more complex and significantly more expensive; yet, using them, one can generate more electric energy.

From the previous paragraph, it can be concluded that relatively complicated and expensive additional devices [6] - solar inverters, electric accumulators and other equipment - have to be used for connecting the consumers to the solar panels. Therefore, the aim of this work is to find ways how to connect solar panels directly to the power consumers $[7 ; 8]$ with active load resistance (electric heaters) and, at the same time, to provide maximum electric production capacity of the solar panels. For this purpose, adjusting the voltage (number) of the solar panels to the consumer's load resistance so that, during the season, the solar panels would be longer (more) operating at or near the maximum power point of the solar panels. To do this, it is necessary to determine the value of the load resistance with which the panel would produce the greatest amount of electricity per year. 


\section{Materials and methods}

The task in order to achieve the goal is to experimentally determine the numerical value of the resistance of a solar panel, loaded with constant active (omic) resistance, at which, under the Latvian conditions, the solar panel would produce the largest amount of electricity during the season; to find the electric power and energy conversion coefficients for such a panel; to analyse and evaluate the solar panels loaded with electric resistances of various values, as well as to determine the amount of power and electric energy produced during a season.

Justification of the choice of the value of the load resistances intended for the experiment.

In order to estimate the output of solar panels, depending on the intensity of solar radiation at a certain temperature $\left(25^{\circ} \mathrm{C}\right)$, a set of V-A characteristic curves of the panel is used. Using the set of the characteristic curves of the panel Dps-275P-60Ws (an analogue to the Solet P6.60-WF-250 panel), given in Fig. 1, and reading the coordinate values of the peak power points, the data, summarised in Table 1 , are obtained, where for solar radiation of $1000 ; 800 ; 600 ; 400 \mathrm{~W} \cdot \mathrm{m}^{-2}$ there are also given the calculated corresponding optimum panel load resistances, which, when applied, would allow the solar panel to operate at a higher power and generate more electricity.

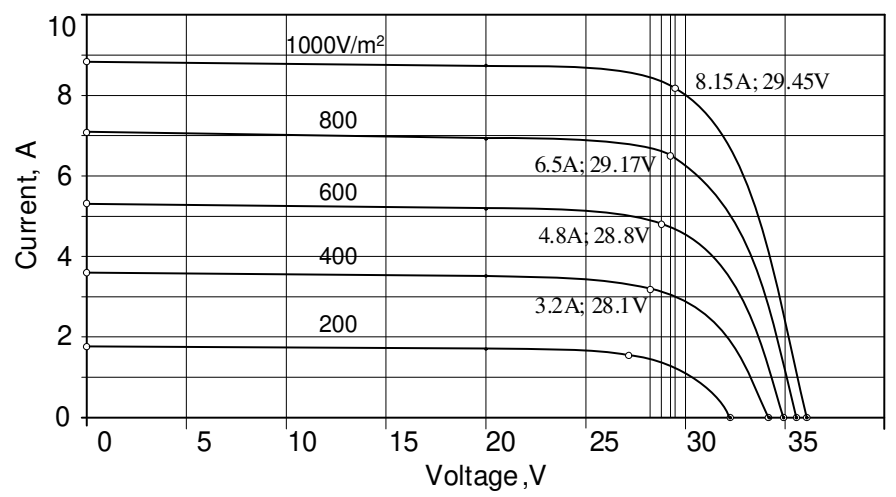

Fig. 1. Set of characteristic curves of the solar panel Dps-275P-60Ws V-A

Table 1

\section{Load resistance $R_{s}$ of the solar panel Dps-275P-60Ws depending on the power of solar radiation on the surface of the panel}

\begin{tabular}{|c|c|c|c|c|}
\hline $\boldsymbol{P}_{\boldsymbol{s t}}, \mathbf{W} \cdot \mathbf{m}^{-2}$ & $\boldsymbol{U}_{\boldsymbol{m p p} \boldsymbol{p}}, \mathbf{V}$ & $\boldsymbol{I}_{\boldsymbol{m p p}}, \mathbf{A}$ & $\boldsymbol{P}_{\boldsymbol{m}}, \mathbf{W}$ & $\boldsymbol{R}_{\boldsymbol{s}}, \boldsymbol{\Omega}$ \\
\hline 1000 & 29.45 & 8.15 & 240 & 3.6 \\
\hline 800 & 29.17 & 6.5 & 189.6 & 4.46 \\
\hline 600 & 28.8 & 4.8 & 138.24 & 6 \\
\hline 400 & 28.1 & 3.2 & 89.92 & 8.78 \\
\hline
\end{tabular}

$P_{s t}$ - solar radiation intensity (power); $U_{m p p} ; I_{m p p}$ - voltage and current at the peak power $P_{m}$ (voltage multiplied by current) point.

The equipment used in the experiment and the data acquisition and processing methodology

A general view of the equipment, used in the experiment, is shown in Fig. 2, where the squares on the surfaces of the panels show the value of the electrical load resistance of the corresponding panel, and the block (1) denotes a block, in which these resistances are located. The panels of the installation Solet P6.60-WF-250 are placed stationary, facing south, at an inclination angle of 42 degrees to the horizon.

Figure 3 shows the electrical circuit diagram of the solar panels (PV) and the data recorders used in the experiment, the right side of which also shows the MMD-4 device [1], used with the sunfollowing, upper thermal battery for the registration of the solar radiation power (intensity) in the data registrator HOBO DATA Logger, $\mathrm{kW} / \mathrm{m}^{2}$. For recording the panel voltage, two HOBO- 1 and HOBO2 recorders are used, which, for the voltage level matching, are connected to the panels with the voltage dividers $\mathrm{R} 1 ; \mathrm{R} 2$. The voltage division factor $k=0.06$ is the same for all the panels. The resistors are selected with precision up to one hundredth of an ohm. With the HOBO-3 and the 
external cylindrical sensor $T_{p}$ (Fig. 3), pressed in the middle of the panel with a polystyrene foam block, the ambient air and temperature at the rear of the panel were recorded. In all Loggers the data are registered for 15 days with an interval of 6 minutes, except for HOBO-3, the data registration of which may take up to 3 months at an interval of 6 minutes. Reloading the data of the Loggers into the computer (twice a month), tables are obtained showing the values of the recorded parameters.

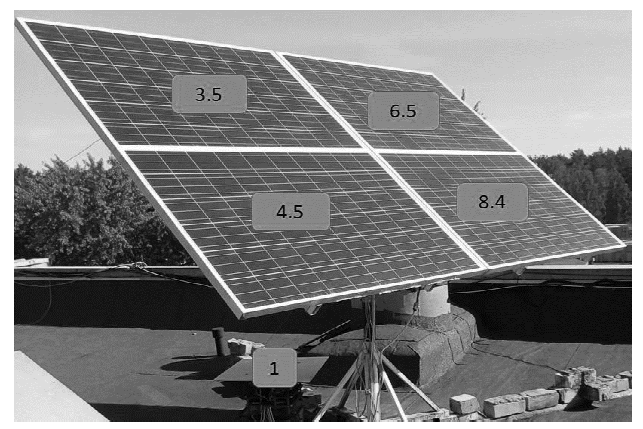

Fig. 2. Overview of the equipment used in the experiment: 1 - load resistance block of the panels; 3.5-8.4 - value $R_{s}$ of electrical load resistance connected to the respective panel

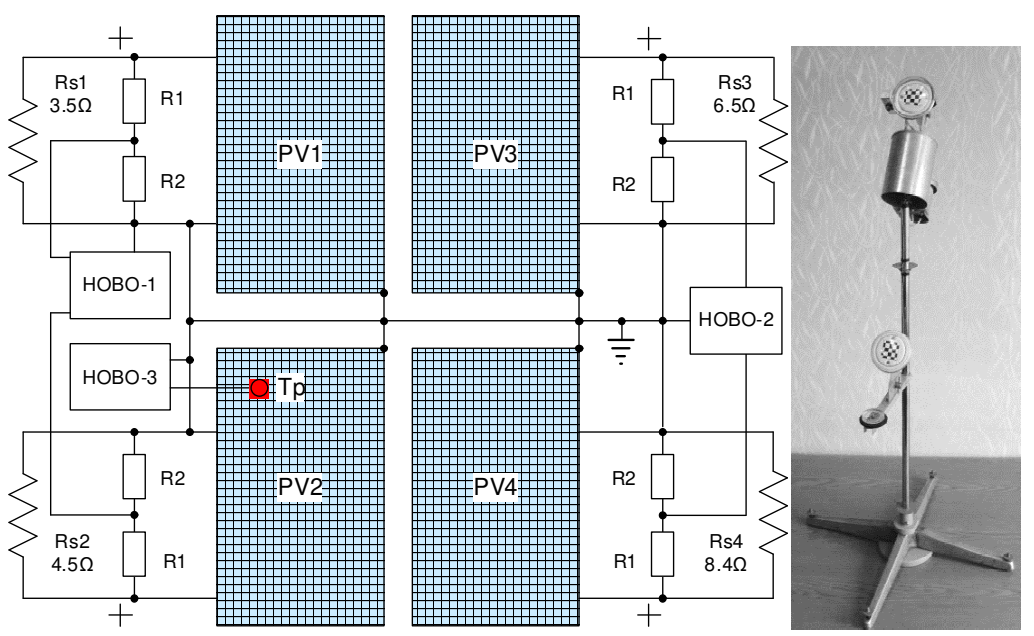

Fig. 3. Electric circuit diagram of the solar (PV) panels and data recorders used in the experiment; MMD-4 device shown to the right

The data were processed by means of the programme Excel. The daily produced power, as a function of time, $P=f(t)$ is calculated using the mathematical function $A B S$ and formula (1). For this purpose on the row of the table, which is designed to calculate the power $P_{i}$, there is a square (cell) marked, the function $f x=A B S$ is opened, and in the square a number, or in the row $f x=A B S$ there are written the parameters of the formula (1) of the operation with numbers. The parameters in the output data table $f x=A B S$ are entered by placing the cursor on the parameter to be recorded and left-clicking the mouse.

$$
P_{i}=\frac{\left(\frac{U_{H i}}{k}\right)^{2}}{R_{s i}},
$$

where $P_{i}-$ at the registration time of the solar panel, W;

$U_{H i}$ - value of voltage recorded in the HOBO Logger, V;

$k$ - partition coefficient of the voltage divider, $\mathrm{k}=0.06$;

$R_{s i}-$ numerical value of the load resistance, connected to the respective solar panel, $\Omega$.

The quantities of the produced electric energy are calculated using the mathematical function SUM formula (2). 


$$
Q=\sum \frac{\left(\mathrm{A}_{\mathrm{i}}: \mathrm{A}_{\text {in }}\right)}{N},
$$

where $Q$ - daytime electric energy produced in a day, $\mathrm{Wh}$;

$A_{i} ; A_{i n}$ - numbers of the beginning and end of the day in the primary data row;

$N$ - number (quantity) of the data registrations per hour.

The coefficients of the power (efficiency) and the produced energy transfer of the solar panels and the energy produced are calculated using [2], respectively, expressions (3) and (4);

$$
\eta_{p}=\frac{P_{p}}{P_{s t} * L_{p}}
$$

where $P_{p}$ - power produced by the solar panel, $\mathrm{W}$;

$P_{s t}$ - power of solar radiation, $\mathrm{Wm}^{-2}$;

$L_{p}-$ working surface of the solar panel, $\mathrm{m}^{2}$.

$$
\eta_{q}=\frac{Q_{p}}{Q_{s t} * L_{p}},
$$

where $Q_{p}$ - energy produced by the solar panel, $\mathrm{Wh}$;

$Q_{s t}$ - value of the solar radiation energy, $\mathrm{Whm}^{-2}$;

$L_{p}$ - surface area of the solar panel, $\mathrm{m}^{2}$.

To estimate the temperature of the solar cell equation (5) is used;

$$
T_{\text {cell }}=T_{\text {air }}+\frac{N O S T-20}{80} S,
$$

where $T_{\text {cell }}$ - temperature of the cell (element) of the panel, ${ }^{\circ} \mathrm{C}$;

$T_{\text {air }}$ - air temperature, ${ }^{\circ} \mathrm{C}$;

NOCT - standard coefficient for the evaluation of the solar panel parameters; for solar panels SoletP6.60-WF-250 the NOCT coefficient is 48.3;

$S$ - power solar radiation, $\mathrm{mWcm}^{-2}$.

In order to find the characteristic features in the operation of the panels loaded with electrical resistances of various sizes $(3.5 ; 4.5 ; 6.5$ and $8.4 \Omega$ ), the statistical function of the empirical distribution method was used (6) to process the energy produced by these panels during the season:

Statistical $\rightarrow$ Frequency $\rightarrow$ Data_array; Bins_array $\rightarrow$ fx $=$ FREQUENCY $(\$ A \$ 1: \$ A \$ 273 ; B 1: B 8)$. (6)

\section{Results and discussion}

Figure 4 and Tables 2 and 3 show the results of the productivity of two solar panels loaded at 3.5 and $4.5 \Omega$ on a clear day, 29.04. 2019. As we can see, at 13:30, when the solar radiation intensity reached $962 \mathrm{~W} \cdot \mathrm{m}^{-2}$, the air and the panel surface temperatures were $17.52{ }^{\circ} \mathrm{C}$ and $33.17^{\circ} \mathrm{C}$, respectively. The power of the solar panel, loaded with $3.5 \Omega$, increased to $243.89 \mathrm{~W}$ and was by $18.93 \mathrm{~W}$ higher than that of the solar panel loaded with $4.5 \Omega$. Calculating the power transfer coefficients according to (3) (Table 3) for a panel loaded with $4.5 \Omega$ it was $15.59 \%$, with $3.5 \Omega-$ $16.9 \%$.

Using formula (2), the energy output, produced daily was calculated, for a panel loaded with 4.5 $\Omega-1.57 \mathrm{kWh}$, and with $3.5 \Omega-1.51 \mathrm{kWh}$. The thermal battery of the sun-following device MDD-4 has registered $10.67 \mathrm{kWh}$ of energy this day, which, in essence, is the energetic value of the energy of the day. Calculating (4) the energy transfer coefficients against this value, we obtain that for a panel, loaded with $4.5 \Omega$, it is $9.8 \%$, and for a panel, loaded with $3.5 \Omega$ it is $9.43 \%$. Since in May [3] the sun-following thermal battery usually registers 1.45 times more energy than the stationary one, then, when converted to the stationary energy, we obtain the energy of solar radiation per day $Q_{s t}=10.67 / 1.45=7.36 \mathrm{kWh}$. Then the energy transfer coefficients are $14.22 \%$ and $13.68 \%$, respectively. 
According to expression (5), at 13:12 (Table 2) the temperature of the panel cell should be $53.49^{\circ} \mathrm{C}$, but the temperature on the back of the panel surface, recorded by the HOBO, is $40.12{ }^{\circ} \mathrm{C}$, which is by $13.36^{\circ} \mathrm{C}$ lower than the estimated (5) one. As already noted, the HOBORpro is pressed against the back surface of the solar panel with a polystyrene foam block. A groove (channel) is formed on the surface of the block, in which the HOBORpro external temperature sensor (cylinder) is inserted. The cylinder is inserted into the groove so deep that its surface slightly passes over the surface of the block and forms a direct contact with the surface of the solar panel. Because of the small diameter of the sensor the contact surface is small and, possibly, insufficient to transfer the required amount of heat from the panel surface to the cylinder. This could be the reason for such a great difference in temperature between the calculated and the recorded one.

It should be noted that on a sunny day, when the clouds are formed that intensively reflect the solar radiation, the capacity produced by the solar panels may exceed $300 \mathrm{~W}$, for instance, in Fig. $5 \mathrm{a}$ panel loaded with $3.5 \Omega$, produces $301.17 \mathrm{~W}$. Nevertheless, the panel loaded with $4.5 \Omega$ still produced by $46 \mathrm{~W}$ more power during this day.

Table 2

Parameters of the solar panels SoletP6.60-WF-250 on a clear day 29.04.2019

\begin{tabular}{|c|c|c|c|c|c|c|c|}
\hline \multirow{2}{*}{ Date and time } & \multicolumn{2}{|c|}{$\begin{array}{c}\text { HOBO-1 } \\
\text { H08-007-02 data }\end{array}$} & \multicolumn{2}{c|}{ Calculated data } & \multicolumn{2}{c|}{$\begin{array}{c}\text { MDD-4 } \\
\text { data }\end{array}$} & \multicolumn{2}{c|}{$\begin{array}{c}\text { HOBO }^{\mathrm{R}} \text { pro } \\
\text { data }\end{array}$} \\
\cline { 2 - 8 } & $U_{4.5 \Omega}, \mathrm{V}$ & $U_{3.5 \Omega}, \mathrm{V}$ & $P_{\mathrm{P} 4.5}, \mathrm{~W}$ & $P_{\mathrm{P} 3.5}, \mathrm{~W}$ & $P_{s}, \mathrm{~W} \cdot \mathrm{m}^{-2}$ & $T g,{ }^{\circ} \mathrm{C}$ & $T p,{ }^{\circ} \mathrm{C}$ \\
\hline $4 / 29 / 1913: 00$ & 1.851 & 1.704 & 211.49 & 230.45 & 962 & 19.04 & 39.22 \\
\hline $4 / 29 / 1913: 06$ & 1.860 & 1.714 & 213.55 & 233.16 & 0.962 & 19.04 & 37.44 \\
\hline $4 / 29 / 1913: 12$ & 1.851 & 1.704 & 211.49 & 230.45 & 0.952 & 19.81 & 40.13 \\
\hline $4 / 29 / 1913: 18$ & 1.880 & 1.724 & 218.17 & 235.89 & 0.962 & 17.9 & 35.27 \\
\hline $4 / 29 / 1913: 24$ & 1.880 & 1.733 & 218.17 & 238.36 & 0.962 & 18.28 & 36.13 \\
\hline $4 / 29 / 1913: 30$ & 1.909 & 1.753 & 224.96 & 243.89 & 0.962 & 17.52 & 33.17 \\
\hline $4 / 29 / 1913: 36$ & 1.880 & 1.733 & 218.17 & 238.36 & 0.952 & 19.04 & 37.88 \\
\hline
\end{tabular}

Note: PP4.5 $=(U 4.5 / 0.06)^{\wedge} 2 / 4.5$; PP4.5 $=(U 3.5 / 0.06)^{\wedge} 2 / 3.5$. File SA180419, in the boxes of the Excel table, row 162, the beginning of the day (the output voltage of the HOBO Logger is greater than the voltage in the darkness), at 5:42, the end of the day at 21:00.

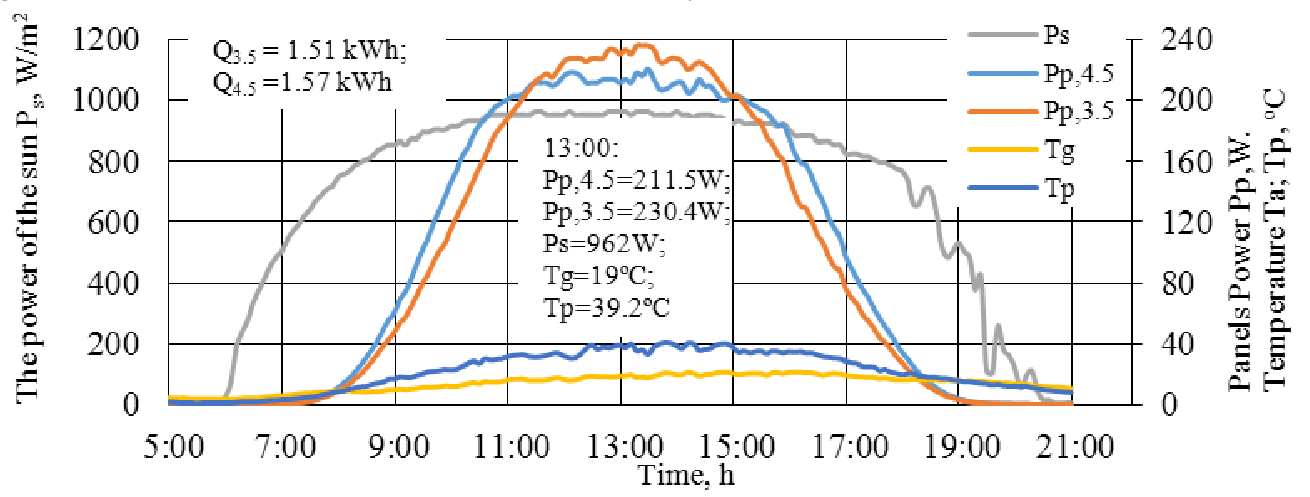

Fig. 4. Parameter graph of the solar panels on a clear day (29.04.2019)

Values of the obtained power and energy conversion (transfer) factors

Table 3

\begin{tabular}{|l|c|c|}
\hline \multicolumn{1}{|c|}{$\begin{array}{c}\text { Conversion factor, \% } \\
\text { 04.29.2019. At 13:18 }\end{array}$} & \multicolumn{2}{|c|}{ Panel load resistance, $\boldsymbol{\Omega}$} \\
\cline { 2 - 3 } & 4.5 & 3.50 \\
\hline Power & 15.59 & 16.90 \\
\hline Energy $\left(Q_{s t}=7.36 \mathrm{kWh} \cdot \mathrm{m}^{-2}\right)$ & 14.22 & 13.16 \\
\hline Energy $\left(Q_{s t}=10.67 \mathrm{kWh} \cdot \mathrm{m}^{-2}\right)$ & 9.80 & 9.43 \\
\hline
\end{tabular}

Using Figure 3, in 2018 and 2019 the capacity of the solar panels was recorded for nine months, and the estimated energy output is summarised in Table 4. All the four panels together have produced $788.7 \mathrm{kWh}$ of electric energy. Most energy $(212.41 \mathrm{kWh})$ has been generated by the solar panel loaded 
with $4.5 \Omega$. It can be concluded that, in case all the panels had a $4.5 \Omega$ load or were connected in series and loaded with $18 \Omega$, they would have produced $850 \mathrm{kWh}$.

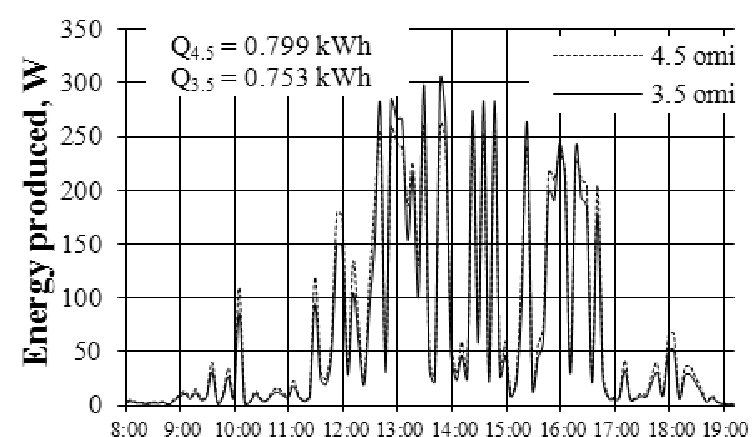

Time, h

Fig. 5. Capacity of the power and energy produced by the panels on May3, 2019

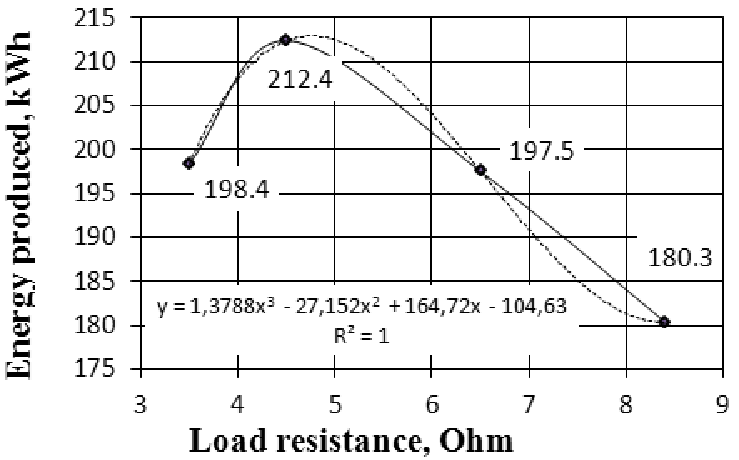

Fig. 6. Power generated by the solar panels SoletP6.60-WF-250 depending on the value of the load resistance

The amounts of energy produced during the period under review are shown in Figure 6, where we can see that allowing slight losses of the produced energy, the value of the load might be between 4.2 and $5 \Omega$. Totally undesirable is the $8.4 \Omega$ load resistance.

Table 4

Energy generated by the solar panels SoletP6.60-WF-250 in 2018 to 2019

\begin{tabular}{|c|c|c|c|c|c|}
\hline \multirow{2}{*}{ Month } & \multirow{2}{*}{ Days } & \multicolumn{4}{|c|}{ Load resistance, $\Omega$} \\
\hline & & 3.5 & 4.5 & 6.5 & 8.4 \\
\hline February & 28 & 6.56 & 7.67 & 7.58 & 7.26 \\
\hline March & 31 & 12.58 & 14.01 & 14.02 & 13.43 \\
\hline April & 30 & 34.73 & 36.82 & 32.82 & 29.59 \\
\hline May & 31 & 27.26 & 28.89 & 26.36 & 24.66 \\
\hline June & 30 & 34.78 & 36.10 & 32.42 & 29.82 \\
\hline July & 31 & 28.13 & 30.04 & 28.75 & 22.98 \\
\hline August & 31 & 25.47 & 27.44 & 26.25 & 24.71 \\
\hline September & 30 & 21.22 & 23.08 & 20.98 & 20.30 \\
\hline October & 31 & 7.68 & 8.36 & 8.32 & 7.58 \\
\hline Total: & 273 & 198.39 & 212.41 & 197.51 & 180.35 \\
\hline
\end{tabular}

In order to analyse and evaluate the operation of the variously loaded solar panels, using expression (6), the data recorded during the season (Table 4, the amounts of the produced energy) are combined in a data array to form four columns with 273 rows and ranked in an ascending order of the numerical values. The data array is divided into the class intervals of the produced energy of $0.2 \mathrm{kWh}$ in each. Applying to them the statistical function, frequency and the mathematical SUM, the amount of energy produced by each solar panel is calculated in the distribution intervals; see histogram in Fig. 7 , and the number of days spent to produce this energy. In Fig. 8 and 9 there are shown the amounts of energy produced by differently loaded solar panels for a 273 days' division of the season into intervals of $(53+55+55+55)$ days.

\section{Discussion}

By calculation and analysis of the set of the V-A characteristic curves (Fig. 1; Table 1) of the solar panel, we succeeded to select for the experiment the load resistance values of the panels (3.5; 4.5; 6.5 and $8.4 \Omega$ ) with sufficient precision. During the 273 days of the entire season, the four solar panels Solet P6.60-WF-250 combined (Table 4) generated $788.7 \mathrm{kWh}(198.39+212.41+$ $+197.51+180.35)$ of electric energy. More energy $(212.41 \mathrm{kWh})$ has been generated by the solar panel loaded with $4.5 \Omega$, the least $(180.35 \mathrm{kWh})$ by the panel loaded with $8.4 \Omega$. If all panels were loaded with a $4.5 \Omega$ load, they could produce $212.41 \cdot 4=850 \mathrm{kWh}$ of electric energy. From Fig. 6 it 
can be concluded that with a reduction in the produced energy by $2 \mathrm{kWh}$, the optimal value of the load resistance of the solar panel Solet P6.60-WF-250 would be within the range of 4.2 to $5.0 \Omega$ (Fig. 6), but with a twice as great power reduction ( $4 \mathrm{kWh} ; 2.1 \%)$, the value of the acceptable load resistance will be within the limits of 4.0 to $5.5 \Omega$, which corresponds to the solar radiation intensity in the set of the VA characteristic curves from 700 to $800 \mathrm{~W} \cdot \mathrm{m}^{-2}$.

Positively appraised is the application of voltage divider coefficients that are equal for all solar panels (Fig. 3), which considerably simplified the processing of the primary data and reduced an error possibility.

As an example of calculation, the application of the calculation methodology of the solar panel parameters and the obtained parameters are shown for a completely clear day (29.05.2019), for which the value of solar energy, recorded with the device MMD-4, was $10.67 \mathrm{kWh} \cdot \mathrm{m}^{-2}$. Then, at the power of solar radiation of $962 \mathrm{Wm}^{-2}$ and the air temperature of $17.52^{\circ} \mathrm{C}$, the solar panel, loaded with $3.5 \Omega$, developed a power of $243.89 \mathrm{~W}$, and the panel, loaded with $4.5 \Omega$, developed $224.96 \mathrm{~W}$ (Table 2), corresponding, respectively, to the power transmission (efficiency) coefficients (Table 3) $16.9 \%$ and $15.59 \%$. Nevertheless, during the day a little more energy was produced by the solar panel loaded with $4.5 \Omega, 1.57 \mathrm{kWh}$ and $1.51 \mathrm{kWh}$, respectively. The corresponding calculated energy transfer factors are $14.22 \%$ and $13.6 \%$. It can be said that they are close to the panel specifications $-15.35 \%$, because during the experiment the radiation power was less than $1 \mathrm{kWm}^{-2}$, and the air temperature was below $25^{\circ} \mathrm{C}$. The maximum generated power $301.17 \mathrm{~W}$ is with the solar panel loaded with $3.5 \Omega$ (Fig. 4).

When analysing the data obtained by the frequency function, Fig. 7, we see that in the $0.2 \mathrm{kWh}$ range of the produced energy there predominates the solar panel loaded with $3.5 \Omega$, which seems illogical; but, regarding simultaneously the solar panel loaded with $8.4 \Omega$, we see that the solar panel loaded with $3.5 \Omega$ in a $0.2 \mathrm{kWh}$ interval has operated more than the solar panel loaded with $8.4 \Omega$.

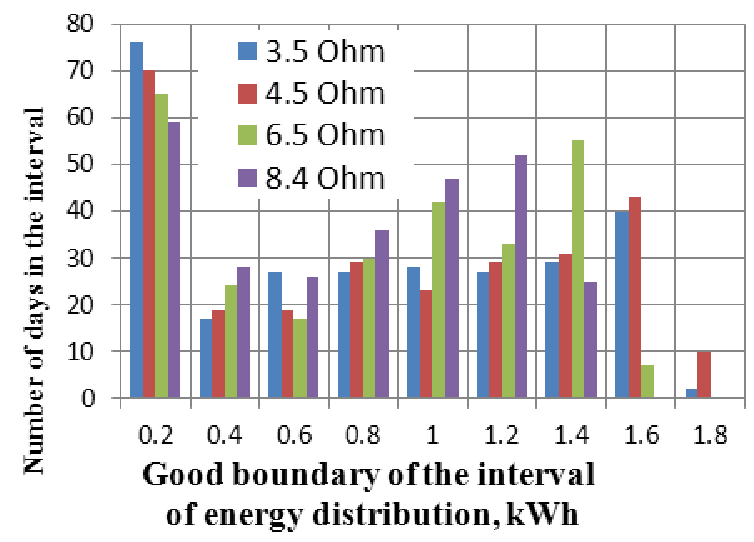

Fig. 7. Distribution of differently loaded solar panels at intervals, based on the amount of energy produced

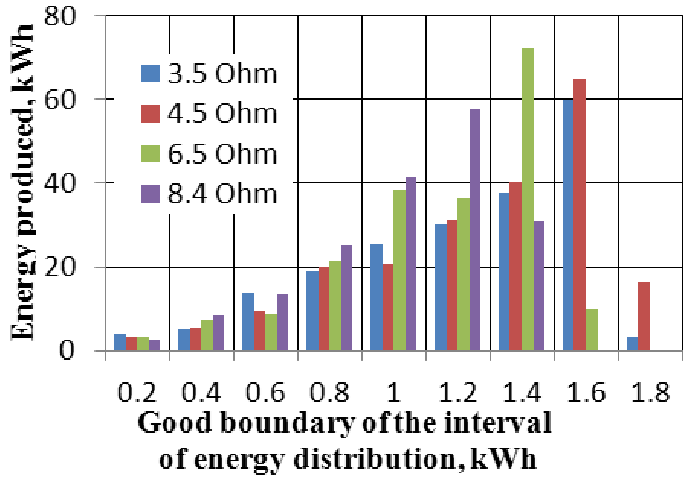

Fig. 8. Distribution of solar panels with different loads at intervals according to the number of days spent for the production of energy

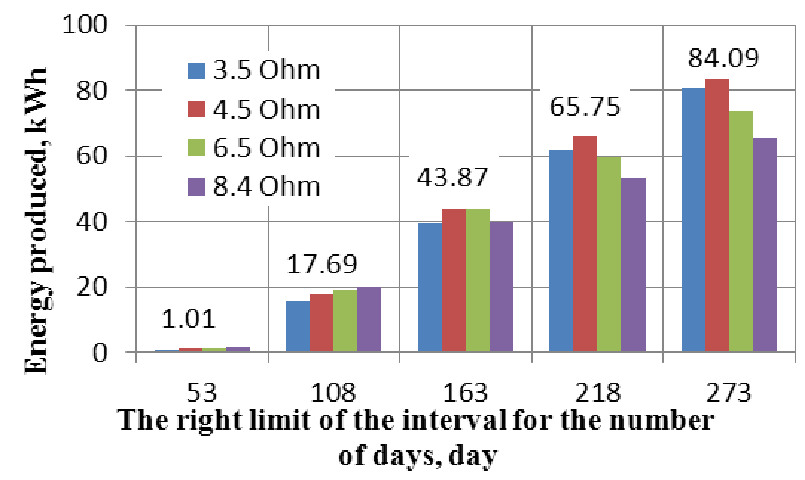

Fig. 9. Distribution of the number of days of the season of the solar panels under different load in increments $(53+55+55+55$ days $)$ in the increasing order of the amount of produced energy 
Analysis of the $1.2 \mathrm{kWh}$ interval indicates that the solar panel loaded with $8.4 \Omega$ has worked and produced electric energy more days. In the interval of $1.4 \mathrm{kWh}$ there prevails the solar panel, loaded with $6.5 \Omega$, and in the interval of $1.6 \mathrm{kWh}$ - the solar panel, loaded with $4.5 \Omega$. In the interval of $1.6 \mathrm{kWh}$ there is no solar panel loaded with $8.4 \Omega$, while in the interval of $1.8 \mathrm{kWh}$ there are neither $8.4 \Omega$ nor $6.5 \Omega$ loaded solar panels, but in the intervals 1.6 and $1.8 \mathrm{kWh}$ the predominant is the solar panel loaded with $4.5 \Omega$.

The data array of Fig. 9 is constructed in an ascending order of the values of the produced power and divided into intervals with a number of days $(53+55+55+55)$. From Fig. 9 it is evident that during the first 108 days more power was produced by the solar panel loaded with $8.4 \Omega$. The interval $108-153$ is symmetrical, producing equally more $(4.5 \Omega$ and $6.5 \Omega)$ and equally less $(3.5 \Omega)$ and $(8.4 \Omega)$. In the greater intervals of the produced energy the predominant is the solar panel loaded with $4.5 \Omega$.

Possibilities of practical application of the results of the work

Table 5 shows example calculation variants of direct connection of two 2 and $4 \mathrm{~kW}$ electric heaters to the solar panels that ensure a load resistance of $4.33 \Omega$ for the solar panels.

Table 5

Possible number of panels in a series, depending on the power of the electric heater

\begin{tabular}{|c|c|c|c|c|c|c|c|c|}
\hline \multirow{2}{*}{\multicolumn{3}{|c|}{$\begin{array}{l}\text { Parameters of the PV panels: } \\
\text { power, } P=0.25 \mathrm{kWp} \text {; voltage, } \\
U_{m p p}=30.9 \mathrm{~V} \text {; current, } I_{m p p}=8.06 \mathrm{~A}\end{array}$}} & \multicolumn{6}{|c|}{ Electric heater, $230 \mathrm{~V}$} \\
\hline & & & \multicolumn{3}{|c|}{$2 \mathrm{~kW} ; R s=26 \Omega$} & \multicolumn{3}{|c|}{$4 \mathrm{~kW} ; R s=13 \Omega$} \\
\hline $\begin{array}{l}\text { Panels in } \\
\text { a series }\end{array}$ & $\begin{array}{c}\text { Voltage } \\
U, \mathbf{V}\end{array}$ & Power, kWp & $\begin{array}{c}\text { Current } \\
\text { I, A }\end{array}$ & $\begin{array}{c}\text { Rsi, } \\
\Omega\end{array}$ & $\begin{array}{l}\text { Power } \\
P, \mathrm{~kW}\end{array}$ & $\begin{array}{c}\text { Current } \\
\text { I, A }\end{array}$ & $\begin{array}{c}\text { Rsi, } \\
\Omega\end{array}$ & $\begin{array}{l}\text { Power } \\
P, \mathrm{~kW}\end{array}$ \\
\hline 1 & 31 & 0.25 & - & - & - & - & - & - \\
\hline 2 & 62 & 0.50 & - & - & - & 4.77 & 6.50 & 0.290 \\
\hline 3 & 93 & 0.75 & - & - & - & 7.15 & 4.33 & 0.665 \\
\hline 4 & 124 & 1.00 & 4.77 & 6.50 & 0.59 & 9.50 & 3.26 & 1.180 \\
\hline 5 & 155 & 1.25 & 5.96 & 5.20 & 0,92 & - & - & - \\
\hline 6 & 186 & 1.50 & 7.15 & 4.33 & 1.33 & - & - & - \\
\hline 7 & 217 & 1.75 & 8.35 & 3.70 & 1.81 & - & - & - \\
\hline 8 & 248 & 2.00 & 9.54 & 3.25 & 2.3 & - & - & - \\
\hline
\end{tabular}

For the calculation of Table 5 elementary regularities of Ohm's law are used. An example of calculation:

$$
\begin{gathered}
I=U / R_{s}=93 / 13=7.15 \mathrm{~A} ; R_{s i}=U p / I=31 / 7.15=4.33 \Omega ; \\
P=U \cdot I=93 \cdot 7.15=665 \mathrm{~W}=0.655 \mathrm{~kW} .
\end{gathered}
$$

Optimal: 3 solar panels with a $4 \mathrm{~kW}$ heater and 6 (5) panels with a $2 \mathrm{~kW}$ electric heater.

Technical data of the measuring instruments used

\begin{tabular}{|c|c|c|c|}
\hline \multirow{2}{*}{$\begin{array}{l}\text { Parameter to be } \\
\text { measured }\end{array}$} & \multicolumn{2}{|c|}{ Measuring instrument used } & \multirow{2}{*}{$\begin{array}{c}\text { Precision (accuracy) of } \\
\text { measurement }\end{array}$} \\
\hline & Brand & Range used & \\
\hline Air temperature & HOBO Pro H08-031-08 & $\begin{array}{c}-30 \\
\text { to }+50^{\circ} \mathrm{C} \\
\end{array}$ & $\begin{array}{c}50^{\circ} \mathrm{C} \text { within the } \\
\text { range } \pm 0.2^{\circ} \mathrm{C}\end{array}$ \\
\hline $\begin{array}{l}\text { Surface temperature } \\
\text { of the panel }\end{array}$ & HOBO Pro H08-031-08 & $\begin{array}{c}-30 \\
\text { to }+50^{\circ} \mathrm{C} \\
\end{array}$ & $\begin{array}{l}50^{\circ} \mathrm{C} \text { within the } \\
\text { range } \pm 0.2^{\circ} \mathrm{C}\end{array}$ \\
\hline $\begin{array}{l}\text { Voltage of the panel } \\
\text { current }\end{array}$ & HOBO H08-007-02 & $0 \ldots 2.5 \mathrm{~V}_{\mathrm{DC}}$ & $\begin{array}{l} \pm 10 \mathrm{mV} ; \pm 3 \% \text { of } \\
\text { reading }\end{array}$ \\
\hline $\begin{array}{c}\text { FINEST } \\
\text { Multimeter }\end{array}$ & Model 707,0 to $100 \mathrm{Vdc}$ & 0 to $10 \Omega$ & $0.05 \%+2$ units \\
\hline
\end{tabular}

Table 6 


\section{Conclusions}

1. On a clear day (29-29-2011), the solar panel, loaded with $3.5 \Omega$ at 13:30, when the power of the solar radiation was $962 \mathrm{~W} \cdot \mathrm{m}^{-2}$, the air temperature was $17.5^{\circ} \mathrm{C}$, produced $244 \mathrm{~W}$ of capacity and $1.51 \mathrm{kWh}$ of electricity per day, but the solar panel, loaded with $4.5 \Omega 4.5 \mathrm{~W}$, produced, respectively, $225 \mathrm{~W}$ and $1.57 \mathrm{kWh}$.

2. The estimated energy transfer coefficients (29.04.2019) for a solar panel, loaded with $4.5 \Omega$, were $14.22 \%$, and for a panel, loaded with $3.5 \Omega-13.16 \%$. According to the technical specifications, the panel SoletP6.60-WF-250 has $15.35 \%$.

3. During the season, from February 1 to October 31, 2018, four solar panels, loaded, respectively, with $3.5 ; 4.5 ; 6.5$ and $8.4 \Omega$, generated $788.66 \mathrm{kWh}$ of electricity. When loaded with $4.5 \Omega$, all the panels could produce $212.41 \cdot 4=850 \mathrm{kWh}$.

4. More energy has generated the solar panel, loaded with $4.5 \Omega,-212.41 \mathrm{kWh}$, the panel, loaded with $3.5 \Omega$, respectively, $197.51 \mathrm{kWh}$, and least of all the panel, loaded with $8.4 \Omega-180.35 \mathrm{kWh}$.

5. By dividing the data array of the amount of electricity produced by the solar panels, loaded with different loads $(3.5,4.5,6.5$ and $8.4 \Omega)$, into the $0.2 \mathrm{kWh}$ intervals and processing by the statistical frequency method, the following is established.

5.1 The maximum number of the consumed (used) days and the smallest amount of the produced energy are within the range up to $0.2 \mathrm{kWh}$. The most consumed days in this range are for the solar panel, loaded with $3.5 \Omega,-76$ out of 273 days, during which only $4 \mathrm{kWh}$ of electrical energy was produced. The smallest number of days consumed in this interval is 8.4 am with a solar panel loaded, and thus also a smaller amount of energy produced $-3 \mathrm{kWh}$. The smallest number of days consumed in this interval is for the solar panel, loaded with $8.4 \Omega$, and thus also the smaller amount of energy produced $-3 \mathrm{kWh}$.

5.2 The best indicator of the amount of the produced electricity and the number of days consumed by intervals up to $1.2 \mathrm{kWh}$, is for the panel, loaded with $8.4 \Omega$, which in 52 days within the interval of $1.2 \mathrm{kWh}$ produced $58 \mathrm{kWh}(1.11 \mathrm{kWh} /$ day $)$ of electric energy.

5.3 In the interval of $1.4 \mathrm{kWh}$, the best indicators are for the panel, loaded with $6.5 \Omega$, that produced the highest amount of energy in 55 days, $72 \mathrm{kWh}(1.31 \mathrm{kWh}$ per day), surpassing by $32 \mathrm{kWh}$ the panel, loaded with $4.5 \Omega$.

5.4 Within the intervals of 1.6 and $1.8 \mathrm{kWh}$ attention deserve only the panels, loaded with 4.5 and

$3.5 \Omega$, with the best indicators of the panel loaded with $4.5 \Omega$, generating $81 \mathrm{kWh}$ of electricity per day, which is an average of $1.35 \mathrm{kWh}$ per day (approximately $1 \mathrm{kWh} \cdot \mathrm{m}^{-2}$ ).

6. By dividing the 273 days of the data array of the solar panels, loaded with various loads $(3.5 ; 4.5$; 6.5 and $8.4 \Omega$ ), that have produced electricity, into intervals $(53 ; 55 ; 55$ and 55 days) in the ascending order and calculating (ABS; SUM) the quantities of energy produced in the interval, we see the following.

6.1 There is regularity that the amount of electricity generated by solar panels in a period of 108 days is proportional to the values of the load resistances, that is to say: in both intervals, least energy was produced by the $3.5 \Omega$ panel and most energy by the $8.4 \Omega$ solar panel.

6.2 In the third interval, when each solar panel generates about $40 \mathrm{kWh}$ of electricity for 55 days, there is symmetry: larger amounts of energy are produced by the panels loaded with 4.5 and $6.5 \Omega$, but slightly smaller amounts with 3.5 and $8.4 \Omega$.

6.3 In the fourth and fifth intervals the best indicator is unequivocally for the solar panel, loaded with $4.5 \Omega$, which in two intervals produced $150 \mathrm{kWh}$ together. The next best indicators in terms of the productivity decline are for the panels, loaded with 3.4, 6.5 and $8.4 \Omega$, respectively. 1.7. When allowing $2.1 \%$ of the energy produced, the load resistance of the SoletP6.60-WF-250 solar panel can be between 4 and 5.5.

7. When allowing $2.1 \%$ losses of the energy produced, the load resistance of the solar panel SoletP6.60-WF-250 under Latvia's conditions may be from 4 to $5.5 \Omega$.

8. When using in practice the panels directly loaded with an active (ohmic) resistance, such as series-produced electric water heaters, in accordance with paragraph 7 and Table 5 of the conclusions, three in series (93V) connected solar panels should use $4 \mathrm{~kW}$, but six in series 
$(186 \mathrm{~V})$ connected panels - a $2 \mathrm{~kW}$ electric water heater. The drawback here is the unused installed capacity.

\section{References}

[1] Salameh Z. Renewable Energy System Design, Elsevier Academic Press, 1st edition, 2014.

[2] Luqu A., Hegedus S. "Handbook of Photovoltaic Science and Engineerin," in Sussex PO__ SQ, pp. 296-297, John Wiley \& Sons Ltd, West Sussex, UK, 2003.

[3] Masters G. M. Electric Renewable and Efficient Power System, JohnWiley \& Sons, 1st edition, 2004.

[4] Salilih E.M., Birhane Y.T. Modeling and Analysis of Photo-Voltaic Solar Panel under Constant Electric Load, Hindawi, Journal of Renewable Energy, Volume 2019, Article ID 9639480, 10 p. DOI: 10.1155/2019/9639480

[5] Singh B., Swamy C. P., Singh B. "Analysis and development of a low-cost permanent magnet brushless DC motor drive for PV-array fed water pumping system," Solar Energy Materials \& Solar Cells, vol. 51, no. 1, 1998, pp. 55-67.

[6] Gonal V. S., Sheshadri G. S. "Solar energy optimization using MPPT controller by maximum conductance method," in Proceedings of the IEEE Power India International Conference (PIICON), IEEE, India, 2016.

[7] Pelece I., Ziemelis I., Putans H., Snegovs A. Improvement of efficiency of PV panels for water heating by changing heater resistance. Latvia University of Life Sciences and Technologies, Latvia Engineering for Rural Development Jelgava, 22.-24.05.2019. pp. 1430-1434.

[8] Putāns H., Zagorska V., Ziemelis I., Kanceviča L., Jesko Ž. Mobilā meteorologísko datu registrēšanas ierīce. Latvijas patents LV 14312 B. Publicēts: Patenti un preču zīmes. Latvijas Republikas Patentu valdes oficiālais vēstnesis. 4/2011., 491. lpp. (In Latvian). 